\title{
DETECTION OF MYCOBACTERIUM IN CLINICAL SAMPLES BY MULTIPRIMER POLYMERASE CHAIN REACTION
}

\author{
Abdulmonam Saied Barouni; Halha Ostrensky Saridakis; Marilda Carlos Vidotto* \\ Universidade Estadual de Londrina, Departamento de Microbiologia, Londrina, PR, Brasil. \\ Submitted: May 17, 2001; Returned to authors: July 11, 2001; Approved: February 10, 2004.
}

\begin{abstract}
We investigated the use of multiprimer-PCR for detection of mycobacteria species in clinical samples. Three different mycobacterial genomic fragments were investigated: the IS6110 insertion sequence, present in $M$. tuberculosis complex; the genus specific fragment (32kDa); and from M. tuberculosis species-specific mtp 40 gene. The sensitivity and specificity using 135 clinical isolates were $94.5 \%$ and $95.9 \%$, respectively, compared with culture in Löwenstein-Jensen medium; the detection limit was $0.05 \mathrm{ng}$ of DNA. In conclusion, this assay is reliable and rapid for detection of Mycobacterium species in clinical samples, and differentiates $M$. tuberculosis from M. bovis strains in a single-step assay.
\end{abstract}

Key words: Mycobacterium tuberculosis, multiprimer-PCR, molecular diagnosis

\section{INTRODUCTION}

Tuberculosis remains a worldwide public health problem; its incidence has increased after the rise of human immunodeficiency virus (HIV) infection and bacterial drug resistance (9). In Brazil, the population presents high rates of tuberculosis, 100.000 cases per year. A differential identification of the type of mycobacteria present in patients is important for the control of the disease and effective antituberculosis treatment. Differentiation between $M$. tuberculosis and other members of the M. tuberculosis complex, which includes human-pathogenic species such as M. bovis e M. africanum, would also be desirable epidemiologically. M. bovis, the cause of tuberculosis in cattle, is a pathogen for a large number of others animals, and its transmition to humans constitutes a public health problem (6).

The definitive diagnosis depends on culture of the mycobacteria, which is a time-consuming and not always sensitive enough. Polymerase chain reaction (PCR), a highly sensitive DNA amplification technique, has been evaluated for detection of $M$. tuberculosis in either cultured strains or noncultured clinical samples, being of special interest for use with those specimens containing few mycobacteria $(5,12,13)$. Although rapid and more sensitive than culture, the use of PCR has been hindered by problems such as contamination and inhibition of the reaction (2). Use of PCR for rapid diagnosis of tuberculosis in a developing country showed $90 \%$ of sensitivity and $81 \%$ of specificity, requiring a standardization of the technique (1). The choice of the target sequence, which should be present in all tuberculosis mycobacteria and absent in all other bacteria, is crucial for the successful use of DNA amplification for detection of those bacteria. Multiprimer PCR system, which involves the use of three sets of primers, each annealing to different bacterial genomic fragments, allowed discrimination between M. tuberculosis, $M$. bovis, and other nontuberculous mycobacteria $(4,7)$.

In this study, the multiprimer PCR system described by Del Portillo et al. (4) was applied to clinical samples in an epidemiological study in Brazil. Sputum specimens $(n=135)$ obtained from patients with respiratory symptoms at the Hospital of Londrina University and at the Central Health Laboratory at Maringá (Paraná State), during 1997 and 1998, were analysed by standard microbiology methods and by PCR. Specimens were digested and decontaminated by the standard protocol with N-acetyl-L-cysteine- $\mathrm{NaOH}$ (3) and used for microscopy by Ziehl-Neelsen staining, culture, and PCR. The samples were

*Corresponding author. Mailing address: Universidade Estadual de Londrina, Departamento de Microbiologia - CCB, Campus Universitário, C.P. 6001. 86051-970, Londrina, PR, Brasil. Tel.: (+5543) 3714396. Fax: (+5543) 3714207. E-mail: macarlos@uel.br 
inoculated on Löwenstein-Jensen slants and incubated at $37^{\circ} \mathrm{C}$ and $25^{\circ} \mathrm{C}$ for 8 weeks, and all colonies isolated were identified by biochemical tests (3). The following strains were used as standards to test the specificity and sensitivity of the reaction: Mycobacterium tuberculosis $\mathrm{H} 37 \mathrm{Rv}$, M. bovis clinical isolate from Brazil-SP, M. avium-intracellulare ATCC 13950, M. chelonae ATCC 946, M. fortuitum ATCC 6841, and M. kansasii ATCC 12478, M. smegmatis (clinical isolate). Staphylococcus aureus ATCC 6538, Streptococcus hemolyticus (clinical isolate) and Acinetobacter baumannii (clinical isolate).

DNA from clinical specimens and bacterial strains were isolated as previously described (4), with some modifications: bacterial strains or pellet from $400 \mathrm{ml}$ of treated sputum were washed in 10x TE (1x TE is 10mM Tris-HCl, pH 8.0; 1mM EDTA) and the pellet was resuspended in $300 \mathrm{ul}$ of TE containing $2 \mathrm{mg} / \mathrm{ml}$ of lysozyme, and incubated for $1.5 \mathrm{~h}$ at $37^{\circ} \mathrm{C}$. This was followed by incubation with $4 \mathrm{ul}$ of proteinase $\mathrm{K}(20 \mathrm{mg} / \mathrm{ml})$, and $30 \mathrm{ul}$ of sodium dodecyl sulfate (SDS) $(10 \%)$ for $1.5 \mathrm{~h}$ at $65^{\circ} \mathrm{C}$. DNA was purified from the aqueous phase by phenol-cloroform (1:1) and precipitated with $0.6 \mathrm{~V}$ of isopropanol and $100 \mathrm{mM} \mathrm{NaCl}$. The pellet was washed with $70 \%$ ethanol and resuspended in $30 \mathrm{ml}$ milli Q water, from which $5 \mathrm{ml}$ were used for the multiprimer PCR.

The multiprimer PCR reaction mixture was prepared in a final volume of $25 \mathrm{ml}$ : PCR buffer (10 mM Tris- $\mathrm{HCl}, 50 \mathrm{mM} \mathrm{KCl}, 1.5 \mathrm{mM}$ $\mathrm{MgCl} 2$ ), 2.5U of Taq polymerase, $0.5 \mathrm{mM}$ each deoxynucleoside triphosphate, 10pmol of MT1: TTCCTGACCAGCGAGCTGCCG and MT2: CCCCAGTACTCCCAGCTGTGC; 15pmol of IS5: CGGAGACGGTGCGTAAGTGG and IS6: GATGGACCGC CAGGGCTTGC; 20pmol ofPT1:CGGCAACGCGCCGTCGGTGG and PT2: CCCCCCACGGCACCGCCGGG; and 5ml of sample DNA. Cycles were initiated at $95^{\circ} \mathrm{C}$ for $5 \mathrm{~min}$, followed by 30 cycles with denaturation at $94^{\circ} \mathrm{C}$ for $1 \mathrm{~min}$, annealing at $68^{\circ} \mathrm{C}$ for $2 \mathrm{~min}$, and extension at $72^{\circ} \mathrm{C}$ for $1 \mathrm{~min}$. The samples were kept for $5 \mathrm{~min}$ at $72^{\circ} \mathrm{C}$ for final extension, and kept at $4^{\circ} \mathrm{C}$ in the thermal cycler until removed for analysis. In each experiment, we included a positive control of $M$. tuberculosis DNA extracted from a culture, as well as a negative control obtained by replacing the sample with milli Q water. The amplification products were visualized by direct analysis of $10 \mathrm{ml}$ on $2.0 \%$ agarose gels containing $0.5 \mathrm{mg} / \mathrm{ml}$ of ethidium bromide, which was electrophoresed in Tris-borate-EDTA (TBE) (89 mM Tris-base, $89 \mathrm{mM}$ boric acid, 2.5mM EDTA). The gel was run at $100 \mathrm{~V}$ for $1 \mathrm{~h}$ and the DNA was visualized by UV transilumination and photographed.

Southern blot hybridization was used to confirm the specificity of PCR products. PCR products, from reference Mycobacterium, electrophoretically separated on agarose gels were transferred onto nylon membranes (Gene Screen Plus). Nylon membranes were incubated with pre-hybridization solution containing $50 \%$ formamide (v/v) deionized, 5x SSC, $0.1 \%$ N-lauroylsarcosine, $0.02 \%$ SDS, $1 \%$ blocking reagent (Boehringer Mannheim) at $42^{\circ} \mathrm{C}$ for $1 \mathrm{~h}$. The probes were labeled with digoxigenin-dUTP by using the primers IS5 and IS6, MT1 and MT2, and PT1 and PT2, and PCR DIG Probe Kit (Boehringer Mannheim) according to the instructions of the manufacturer.

The multiprimer PCR assay showed three DNA bands, which correspond to a 984-pb amplification fragment from the IS6110 insertion sequence present in $M$. tuberculosis complex, a 506bp amplification fragment from the gene for the 32-KDa antigen, which is present in most of the species belonging to the genus Mycobacterium, and a 396-bp fragment from the speciesspecific MTP40 gene of M. tuberculosis (Fig. 1).

What concerns specificity of this assay, considering standard mycobacterial species and other bacterial species, only M. tuberculosis presented all three bands, whereas the 506-bp band was detected in all Mycobacterium. No amplification products were observed in Staphylococcus aureus, Streptococcus hemolyticus and Acinetobacter baumannii. Southern blot hybridization confirmed the specificity of the amplified products. M. tuberculosis and M. bovis hybridized with the DIG labeled 984 bp fragment IS, whereas hybridization was not observed with samples of nontuberculous mycobacteria and other strains. DIG labeled $506 \mathrm{bp}$ MT probe hybridized with all mycobacteria, and DIG labeled 396 bp PT probe hybridized only with $M$. tuberculosis (data not shown). The sensitivity of this assay was evaluated by using serial dilutions of DNA (50ng to $50 \mathrm{fg}$ ) from three clinical samples, quantified by Fluorometer DyNA (200 Hoefer Pharmacia); the limit of detection was $0.05 \mathrm{ng}$ (data not shown).

Of the 135 sputum samples examined, 26 presented acid-fast bacilli by Ziehl-Neelsen staining (positive smears). Growth on Löwenstein-Jensen slants (positive culture) was obtained with 37 samples, 35 of which were identified as M. tuberculosis, one sample was identified as M. avium and another as M. fortuitum. Thirty-nine samples were positive by multiprimer PCR. Fig. 1 shows multiprimer PCR amplified bands of DNA from $M$. tuberculosis and M. bovis in clinical samples, some of which were negative in Ziehl-Neelsen stain or in culture.

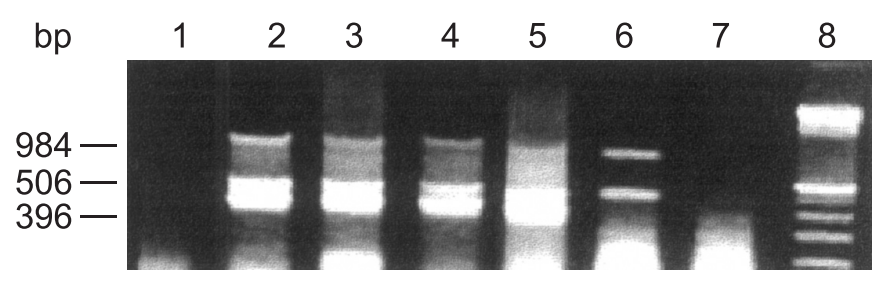

Figure 1. Detection of M. tuberculosis and M. bovis in clinical samples after amplification with PCR multiprimer. The PCR products were then analyzed by eletrophoresis in $2 \%$ agarose gel stained with ethidium bromide. Lane 1, negative control without target DNA; lane 2, 4, 5, 6 and 7, smear +/ culture +; lane 3 , smear -/ culture +; lane 8 , smear -/ culture - samples identified as M.bovis; lane 9, smear - / culture - ; lane 10, MW bp100. 
The correlation between multiprimer PCR and the smears and culture is shown in Table 1. With the exception of two samples, all the samples positive by Ziehl-Neelsen staining or in culture were also positive by multiprimer PCR. In contrast, four samples, which had given negative results in convencional tests, were positive by multiprimer PCR. Thirty five samples ( 25 smear-positive and 10 smear-negative) were multiprimer PCR and culture positive. The sensitivity of this method for sputum, compared to that of cultures, was $94.5 \%$ and the specificity was $95.9 \%$. Only two samples with positive cultures were PCR negative, but four samples with negative cultures were PCR positive. The presence of two false-negative samples by this method can be due to insuficient amount of samples or the presence of inhibitors. Other authors found lower sensitivity (88\%) for two-band multiprimerPCR to detect $M$. tuberculosis in clinical specimens (7).

The results obtained in this study with multiprimer PCR are similar to those reported by other authors using single step PCR. However, it is difficult to compare the results obtained by those groups, since not only extraction and purification procedures were different, but the methodology and target sequence were also different. Pao et al. (8), using primers from $65 \mathrm{kDa}$ protein, found a correlation between PCR and bacteriology data with sensitivity of $100 \%$ and specificity of $62.6 \%$. Querol et al. (10) studied 314 respiratory samples and found a correlation between culture and PCR in 97\%, using primers from IS6110. Thoe et al. (13), evaluating Amplicor- and IS6110-PCR for detection of M. tuberculosis complex in Singapore, detected $86.5 \%$ and $83.6 \%$ of sensitivity and specificity, respectively; and suggested that size of inoculum, nonuniform samples due to clumping effect of mycobacteria, and the absence of target gene sequences for IS6110-PCR, were the reasons for false negative results. Rajalahti et al. (11) using automated Cobas Amplicor MTB PCR found sensitivity of $83 \%$ for this method.

Table 1. Detection of $M$. tuberculosis in sputum by multiprimer PCR.

\begin{tabular}{lcccc}
\hline Microscopy & Multiprimer & \multicolumn{2}{c}{$\begin{array}{c}\text { Number of samples with } \\
\text { the following culture result }\end{array}$} \\
\hline \multirow{4}{*}{ Positive } & & Positive & Negative & Total \\
\cline { 3 - 5 } & Positive & 25 & 0 & 25 \\
& Negative & 1 & 0 & 1 \\
& Total & 26 & 0 & 26 \\
Negative & Positive & 10 & 4 & 14 \\
& Negative & 1 & 94 & 95 \\
& Total & 11 & 98 & 109 \\
& Positive & 35 & 4 & 39 \\
& Negative & 2 & 94 & 96 \\
& Total & 37 & 98 & 135 \\
\hline
\end{tabular}

Similar to the results of Del Portillo et al. (4), we also identified M. tuberculosis and M. bovis in addition to other nontuberculosis mycobacteria. This multiprimer system has the advantage of discriminating $M$. tuberculosis and $M$. bovis from nontuberculosis mycobacteria in a single step within $48 \mathrm{~h}$, and should be easy to use in most microbiology laboratories since detection can be achieved by simple agarose electrophoresis. This is important due to an increase in tuberculosis, mycobacterial diseases caused by nontuberculous mycobacteria, and infections by more than one mycobacterial species in immunosuppressed patients. Also, $M$. bovis has not been eradicated in Brazil and $M$. bovis BCG strains are widely used as a vaccine to prevent tuberculosis; therefore its differentiation from M. tuberculosis has additional public health implication (9).

The results presented in this study indicate that the multiprimer method improves tuberculosis diagnosis, with the advantage that this method is more rapid and more sensitive than classical bacteriology methods. This method could be applied directly to clinical samples in medical and veterinary laboratories, and can be used to differentiate M. tuberculosis from M. bovis strains.

\section{ACKNOWLEDGMENTS}

We thank Prof. Olavo F. Ferreira Filho (Hospital Universitario de Londrina), and Profa Rosilene Fressatti Cardoso (Universidade de Maringa) for providing the reference clinical isolates and for identification of bacteria in clinical samples, and Prof. Dr. Luis Carlos Jabur Gaziri for reviewing the manuscript.

\section{RESUMO}

\section{Detection of Mycobacterium in clinical samples by multiprimer polymerase chain reaction}

PCR utilizando vários oligonucleotídeos para detecção de espécies de micobactérias em espécimes clínicas foi padronizado. Três diferentes fragmentos genômicos: da sequiência de inserção IS6110, presente no complexo M. tuberculosis, do gene responsável por proteína específica $(32 \mathrm{kDa})$ do gênero e do gene mtp40 espécie-específico do M. tuberculosis foram estudados. A sensibilidade e especificidade do método em 135 amostras clínicas foram de $94.5 \%$ e $95.9 \%$, respectivamente, comparados com os resultados da cultura em meio LöwensteinJensen, e o limite de detecção foi de 0.05 ng of DNA. O ensaio mostrou-se confiável e rápido para deteç̧ão de espécies de Mycobacterium em amostras clínicas, diferenciando $M$. tuberculosis de M. bovis em uma única reação.

Palavras-chave: Mycobacterium tuberculosis, diagnóstico molecular, IS6110, gene $m t p 40$, PCR 


\section{REFERENCES}

1. Bollela, V.R.; Sato, D.N.; Fonseca, B.A. Problems in the standardization of the polymerase chain reaction for the diagnosis of pulmonary tuberculosis. Rev. Saude Publica, 33(3): 281-286, 1999.

2. Butcher, P.D.; Hutchinson, N.A.; Doran, T.J.; Dale, J.W. The application of molecular techniques to the diagnosis and epidemiology of mycobacterial diseases. J. Applied. Bacteriol., 81: 53S-71S, 1996.

3. David, H.; Levy-Frebault, V.; Thorel, M.F. Mèthodes de laboratoire pour mycobactériologie clinique. Institut Pasteur, Paris, 1989, 84p.

4. Del Portillo, P.; Thomas, M.C.; Martínez, E.; Maranón, C.; Valladares, B.; Patarroyo, M.E.; López, M.C. Multiprimer PCR system for differential identification of Mycobacteria in clinical samples. $J$. Clin. Microbiol., 34:324-328, 1996.

5. Eisenach, K.D.; Sifford, M.D.; Cave, M.D.; Bates, J.H.; Crawford, J. T. Detection of Mycobacterium tuberculosis in sputum samples using a polymerase chein reaction. American Review Respiratory Disease, 144: 1160-1163, 1991.

6. Hardie, R.M.; Watson J.M. Mycobacterium bovis in England and Wales: past, present and future. Epidemiol. Infect., 109: 23-33, 1992.
7. Mustafa, A.S.; Abal, A.T.; Chugh, T.D. Detection of Mycobacterium tuberculosis complex and non-tuberculous mycobacteria by multiplex polymerase chain reactions. East Mediterr Health J., 5(1):61-70, 1999.

8. Pao, C.C.; Benedict, T.S.; You, J.B.; Maa, J.S.; Fiss, E.H.; Chang, C. Detection and identification of Mycobacterium tuberculosis by DNA amplification. J. Clin. Microbiol., 28:1877-1880, 1990.

9. Parry, C.; Davies, P.D.O. The resurgence of tuberculosis. J. Applied. Bacteriol., 81: 23S-26S, 1996.

10. Querol, J.M.; Farga, M.A.; Granda, D.; Gimeno, C.; García-de-Lomas, J. The utility of polymerase chain reation in the diagnosis of pulmonary tuberculosis. Chest, 1631-1635, 1995.

11. Rajalahti, L.; Vuorinen, P.; Nieminen, M.M.; Miettinen, A. Detection of Mycobacterium tuberculosis complex in sputum specimens by automated Roche Cobas amplicor Mycobacterium tuberculosis test. J. Clin. Microbiol., 36: 975- 978, 1998.

12. Sechi, L.A; Dupre I.; Sanguinetti M.; Fadda G.; Zanetti S. Simple and rapid identification of different species of Mycobacteria by PCR. Mol. Cell Probes, 13(2): 141-6, 1999.

13. Thoe, S.Y.; Tay, L.; Sng, E.H. Evaluation of amplicor- and IS6110PCR for direct detection of Mycobacterium tuberculosis complex in Singapore. Trop. Med. Inter. Health, 2: 1095-1101, 1997. 